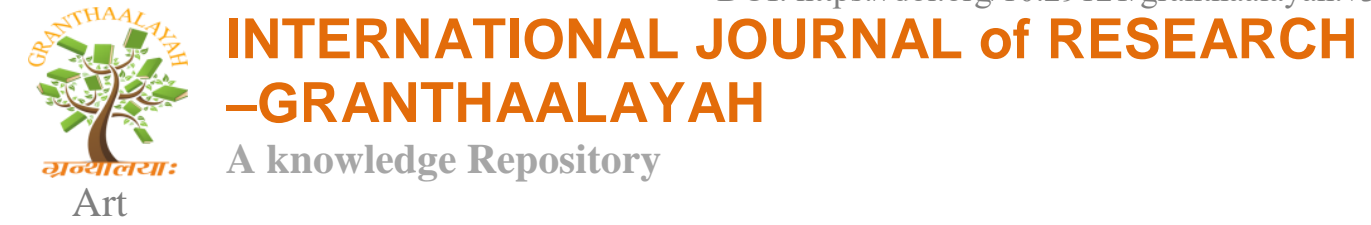

\title{
RHYTHMIC BEAUTY IN THE PLAYS OF RENAISSANCE
}

\author{
Dr. Kehkashan Khan \\ Assistant Professor \\ Govt. Maharani Laxmi Bai Girls P.G. College, Fort, Indore
}

The Theatres were very much in vogue in the Elizabethan England. For the spectators, theatres were not merely places of amusement $\&$ entertainment but also of social gathering $\&$ instruction. Both Marlowe \& Shakespeare are great dramatists \& poets of Elizabethan age. Their poetry \& music lend a unique power \& beauty to their plays.

Marlowe, the predecessor of Shakespeare, infused his own soul into his characters like a lyric poet. He is regarded as the Morning Star of Song \& the first \& foremost lyricist of English Stage. He poetized the English dramas. His play Doctor Faustus reads more like a poem than a drama. His passage on Helen is one of the loveliest of lyrics. In its idealization of beauty, in its riot of colour, in its swift transition from one myth to another, in music \& melody, in its passionate exuberance $\&$ abundance the passage remains unsurpassed.

Was this the face that launched a thousand ships

And burnt the topless towers of Ilium?

Sweet Helen, make me immortal with a Kiss.

Her lips suck forth my soul! See where it flies !

Come Helen, come give me my soul again -

Here will I dwell, for Heaven is in these lips: ${ }^{1}$

In the following passage Marlowe's imagination glows with a dazzling brightness \& the feeling is given voice with the same rich phrasing $\&$ the sonorous music in the words. Faustus tells of the highest delights his magic has brought him :

Have not I made blind Homer sing to me

Of Alexander's love an oenon's death?

And hath not he, that built the walls of Thebes

With ravishing sound of his melodious harp,

Made music with my Mephistophilis ? ${ }^{2}$

Marlowe is the poet of passion par excellence. Passion like fire burns through the verse of Marlowe giving it glow \& radiance. It sweeps through the following lines!

An my good Lord, be patient, She is dead ;

And all this raging cannot make her live :

If words might serve, our voice hath rent the air ;

If tears, our eyes have watered all the earth; 


\section{INTERNATIONAL JOURNAL Of RESEARCH -GRANTHAALAYAH

If grief, our murdered hearts hath stream forth blood;

Nothing prevails, for she is dead, my lord. ${ }^{3}$

Music is an essential feature of the world of Shakespearean drama. It is of various kinds : There is the court music of Duke Orindo, the traditional. music of the clown played on pipe \& tabor ; popular songs like those of Sir Andrew in Twelfth Night, of Amiens in 'As you Like It', of Balthasar in 'Much Ado About Nothing' \& so on "Shakespeare gave the brightest jewels of Humanist poetry in a manner which his audience could enjoy \& appreciate, even though they might not understand it. It is for this reason that drama became so popular and also the finest product of Renaissance humanism in England". ${ }^{4}$

The Moonlight Scene in 'The Merchant of Venice' is permeated with music \& romance. After the strain of \& anxiety of the Trial-Scene, the audience relax leisurely in the lap of nature where under the canopy of the bright sky in the fragrance of flowers and shrubs, the ear is soothed with the rich sweet music which goes to calm the agitated hearts with almost religious adoration. Lorenzo gives vent to his lyrical outburst:

How Sweet the moonlight sleeps upon this bank;

Here we will sit and let the sound of music,

Creep in our ears; soft stillness and \& the night,

Become the touches of Sweet harmony. ${ }^{5}$

It is to be noted that music is the food of love. The witchery \& the music of the poetry of the comedies as well as tragedies enthrall us. Shakespeare firmly believes that music is an essential part of life. He accepted the dross \& the gold, the beauty \& the ugliness Poetry, the supreme expression of imagination has a universal appeal and Shakespeare has made excellent use of it.

The man that hath no music in himself

Nor is not moved by the concord of Sweet Sounds

Is fit for treason, stratagems and spoils. ${ }^{6}$

Lear and Pericles become mad, and music brought about their sanity. Music has the power to calm the 'wild and wanton herd' and to control the race of youthful \& unhandled colts.

Shakespeare is the king of poetic rhythm and style as well as the king of the realm of thought. Shakespeare has succeeded in giving us the most varied, the most harmonious verse which has ever sounded upon the human ear since the verse of the Greeks. Like his play Tempest, no other drama in the whole range of Jacobean theatre portrays such an extensive \& unified treatment of music. The enchanted island is full of sound \& sweet airs that give delight and hurt not. There is both vocal \& orchestral music. It is of far reaching significance. It is the instrument by which discord is turned into harmony and Prospero, the king is able to solve all his problems one by one. The two lovers Ferdinand \& Miranda are brought together by the Music of Ariel. Ariel invites Ferdinand to come on the land from the sea. 


\section{INTERNATIONAL JOURNAL Of RESEARCH -GRANTHAALAYAH \\ A knowledge Repository}

Art

Come unto these yellow sands,

And then take hands;

Courtside when you have and kissed

The wild waves whist,

Food it featly here \& there

And sweet spirits, the burden bear. ${ }^{7}$

Ferdinand takes the song to be sung by some divine being and as soon as he sets his eyes on Miranda, he thinks her to be the goddess of the island \& attributes the music to her.

Thus Shakespeare's vision of life, his wonderful characterization, his broad humanity, his sense of humor \& tolerance, his catholicity of out look, his dramatic art have all found an eloquent expression in his magnificent poetry \& music.

\section{REFERENCES}

1 Marlowe Christopher: Complete Plays and Poems Ed. By E.D. Pendry \& J.C. Maxwell (London : J.M. Dent \&Sons Ltd. : 1983), P. 320

2 Ibid; P. 289

3 Ibid; P. 83

4 Entwisted, A.R. 'The Study of Poetry', Thomas Nelson \& Sons; London, 1928

5 Shakespeare William: 'The Complete works' ed. By Peter Alexander; (London: Collins, 1959)

6 Ibid; P. 250

7 Ibid; P. 7 